\title{
Kerkliedere met 'n lae gebruiksfrekwensie: Speel die melodie 'n rol?
}

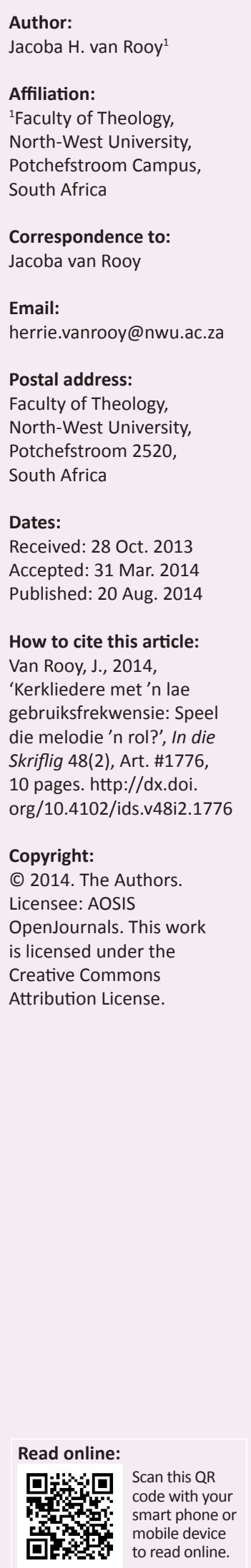

Enige kerklike liedboek bevat liedere wat dikwels tydens eredienste gesing word en liedere wat min of nooit gesing word nie. Hierdie toedrag van sake kan aan 'n verskeidenheid faktore toegeskryf word. In sommige gevalle mag die inhoud van 'n lied dalk liturgies nie maklik bruikbaar wees nie. Daar is egter gevalle waar die inhoud liturgies bruikbaar is, maar waar die liedere steeds nie dikwels in die liturgie gebruik word nie. Ook hiervoor kan daar verskillende redes wees. Soms word die melodieë van die liedere as die rede aangevoer waarom dit weinig gesing word. Hierdie artikel ondersoek die aangeleentheid met verwysing na 'n aantal liedere wat min gebruik word volgens die bevindings van 'n empiriese ondersoek na die gebruik van liedere in die Gereformeerde Kerke in Suid-Afrika (GKSA). Die artikel gee aandag aan die vereistes vir en die funksie van kerkliedere as agtergrond vir die beoordeling van 'n aantal liedere. Die resultate van die empiriese ondersoek is vir die keuse van die melodieë gebruik wat in hierdie artikel bespreek word. Die melodieë van die betrokke vyf liedere word bespreek en geëvalueer om te bepaal of dit moontlik 'n rol kan speel in die lae gebruiksfrekwensie daarvan. Die artikel toon aan dat die melodie wel 'n belangrike aanduider in die lae gebruiksfrekwensie van die liedere is.

Hymns used infrequently: Does the melody play a role? Any hymn book contains hymns that are sung frequently during services and other hymns that are sung very rarely or even never. This fact can be ascribed to a number of reasons. In some instances the contents of the hymn are such that it does not fit easily into the liturgy of a service. There are, however, hymns that could easily be used in the liturgy, but are used infrequently. Different reasons can account for this. The melodies of such hymns are often blamed for this state of affairs. This article explores this issue with respect to a number of hymns that are utilised infrequently according to data from an empirical investigation into the frequency of the use of hymns in the Reformed Churches in South Africa (RCSA). This article discusses the requirements for and the function of ecclesiastical hymns as background for the evaluation of a number of hymns. Results from an empirical investigation were used for the selection of melodies discussed in this article. The article then discusses and evaluates the melodies of five hymns that are used very infrequently in the churches to determine whether these melodies impacted negatively on the use of these hymns. From this discussion it is evident that the melody plays an important role in the low frequency use in the liturgy.

\section{Inleiding}

In enige kerklike liedboek kom liedere voor wat min of nooit tydens eredienste gesing word nie. Hiervoor kan verskillende redes aangevoer word, byvoorbeeld dat ' $n$ lied nie werklik liturgies bruikbaar is nie soos Psalm 137, waar die oordeel van God afgebid word oor die vyande van die digter en sy volk. Tog is daar liedere waarvan die inhoud wel liturgies bruikbaar is, maar wat nie in eredienste gesing word nie. Hiervoor word die melodie van die betrokke lied soms geblameer soos blyk uit die bespreking van die standpunt van Vos en Müller (1990) hieronder. In hulle (Vos \& Müller 1990:94) bevinding waarom liedere nie gesing word nie, word 'n onbekende of problematiese melodie tesame met die inhoud wat nie geskik is nie as die drie redes daarvoor genoem. Hierdie artikel wil bepaal of die melodie 'n rol kan speel by ' $n$ aantal kerkliedere wat, volgens ' $n$ empiriese ondersoek, weinig gesing word. Eerstens word opmerkings gemaak oor die vereistes vir en die funksies van die kerklied. Daarna volg 'n bespreking oor die redes wat aangevoer word waarom sekere liedere 'n lae gebruiksfrekwensie het. Dit word gevolg deur 'n kort beskrywing van die empiriese ondersoek waarop die keuse van die melodieë wat bespreek gaan word, berus. Daarna word die melodieë van vyf liedere bespreek, waarna enkele konklusies gemaak word.

\section{Die kerklied: Vereistes en funksies}

In hierdie afdeling word net enkele opmerkings gemaak oor die vereistes en funksies van die kerklied. Dit word elders in meer besonderhede bespreek (vgl. Van Rooy 2009:259-274). Die 
kerklied is ' $n$ wesenlike deel van die liturgie van die erediens in alle Christelike tradisies. Dit is ' $n$ saak waaroor die Bybel duidelik uitsluitsel gee en wat dwarsdeur die geskiedenis 'n belangrike plek in die erediens verkry het (Van Rooy 2009:178). McKinnon (2001:795) beskou die kerklied as deel van kerkmusiek wat komponente soos himnodie, psalmodie, deklamasie en akklamasie bevat en wat deur Christene in 'n verskeidenheid byeenkomste gebruik word. De Heer (1999:77-78) gee aandag aan die feit dat die woord kerklied uit twee elemente bestaan (kerk en lied). Kerk dui aan dat dit liedere vir die kerk is. Die kerk het ontstaan deur Jesus Christus se koms na die wêreld. Die lidmate het gemeenskap met Hom en daar word 'n gemeenskap deur Hom gevorm. Die kerk is nie bloot iets van die oomblik nie, maar maak deel uit van die kerk van alle tye en plekke. Die kerklike lewe het 'n sentrum, naamlik die weeklikse samekomste, die erediens. Wat die lied betref, moet verskillende fasette in gedagte gehou word, naamlik die inhoud, die teks en die melodie. Hierdie drie fasette vorm 'n eenheid en kan nie van mekaar losgemaak word nie. Samevattend kan 'n kerklied beskou word as 'n lied wat veral in eredienste gebruik word en waarvan die inhoud die gelowiges se geloof verwoord en waarin hulle op die verkondigde Woord reageer (Van Rooy 2009:259). In die gereformeerde tradisie, waarop hierdie artikel fokus, word waarde geheg aan sake soos die skriftuurlikheid van die kerklied en die literêre en musikale kwaliteit daarvan. Ten opsigte van Psalmberyming beskou Vos (2005:354-356) 'n beryming as betroubaar wanneer dit die ritmiese beweging en metaforiese struktuur van die Hebreeuse psalm volg. Die woorde en die melodie van die lied behoort in fyn balans te wees (die sogenaamde woord-toonverhouding; Van Rooy 2009:274). Hoondert (2003:72) het 'n studie van die ontwikkeling van die woordtoonverhouding gedurende die afgelope drie dekades gemaak. Volgens hom verteenwoordig die ontwikkeling van liturgiese liedere 'n golfbeweging. Voor die tagtigerjare van die vorige eeu was die fokuspunt die teks. Daarna het die taal van die musiek meer op die voorgrond getree. Nuwe, meer musikale genres het na vore getree. Die melodie dien nie net die teks nie, maar verklank dit ook op 'n eie wyse.

Wat die funksies van die kerklied aanbetref, stel Kennel (2004:102) dit duidelik as hy sê: 'Gottesdienstliche Musik ist funktionale Musik.' Daar kan veral vier belangrike sake genoem word, naamlik lof en belydenis, verkondiging, gebed en smeking asook die gemeenskapsopbouende funksie (Rössler 1994/1995:118-119; Smelik 1998:182-187; 2005:63; Kruger \& Smit 2001:21-22). Lofprysing en belydenis kom duidelik na vore wanneer God se heilsdade en wat daarmee saamgaan in herinnering geroep word. Hierdie twee elemente is onlosmaaklik aan mekaar verbonde. Wanneer die lied die funksie vervul om God se dade te loof en te bely, impliseer dit dat die dade verkondig word. Volgens die Bybel bestaan daar ' $n$ duidelike verwantskap tussen lofprysing en verkondiging, byvoorbeeld in 1 Petrus 2:9, Psalm 22:23 en 71:14-16. Die verkondigende funksie word in die Skrif op plekke veronderstel waar die lied die funksie vervul om God se Woord in die gemeente te laat woon. Wanneer lidmate mekaar onderling in die lied vermaan en leer, word die Woord van God in die gemeente oorgedra. Gebed en smeking kom duidelik in liedere uit die Skrif voor waarin daar gekla en gesmeek word en waarin voorbidding gedoen word. Die bedoeling is dat 'n beroep op God se belofte of woorde uit die verlede gedoen word op grond waarvan Hy gevra word om aan sy skepping (sy volk, die digter of sanger) te dink. Hieroor word die vertroue uitgespreek dat God in die hede en in die toekoms handelend sal optree en dat dit daartoe sal lei dat God geprys word. In smeekgebede is skuldbelydenis en die lofprysing van God baie nou verweef, byvoorbeeld in 1 Johannes 1:9. Tog waarsku Smelik (2005:58-59) dat die lied oor God handel soos Hy Homself in sy Woord en werke geopenbaar het. Dit is nie die aktiwiteite van mense nie, maar God wat in die middelpunt staan. Die gemeenskapsopbouende funksie van die kerklied is elders in detail bespreek (Van Rooy 2013).

In die kerklied is sprake van 'n drieledige beweging, naamlik van God na die mens, van die mens na God en van die mense na mekaar. Al die funksies kan in een lied teenwoordig wees, maar dit is nie noodwendig so nie. 'n Kerklied kan dus 'n ryke skakering van funksies vertoon wat nie altyd van mekaar te skei is nie (De Heer 1999:77-78). 'n Waardering vir die kerklied binne die kerk hang nou saam met die beeld wat daaromtrent bestaan. Daar moet respek wees en ruimte vir diversiteit in die kerklied gegee word ten opsigte van melodie, teks en die taalregister waarin die liedere geskryf is. Dit weerspieël 'n verskeidenheid in die kerk (Smelik 1999:134).

\section{Redes waarom liedere nie gesing word nie}

Vos en Müller (1990:94) bespreek in 'n artikel belangrike gegewens na aanleiding van 'n empiriese ondersoek oor kerksang in drie Afrikaanse kerke (Nederduitse Gereformeerde Kerk, Nederduitsch-Hervormde Kerk van Afrika en die Gereformeerde Kerke van Suid-Afrika) met die oog op die nuwe psalmberyming. Hulle vind veral drie redes waarom sekere psalms nie gesing word nie, naamlik 'n onbekende melodie, 'n problematiese melodie en die inhoud van 'n lied. In hierdie verband het Ramshaw (1995:16) die vraag gevra of alle liedere in liedbundels vir liturgiese gebruik geskik is. Dit impliseer die vraag watter tekste die moeite werd is om gesing te word. Sommige liedere is geliefd vanweë die melodieë. Hoeveel liturge lees elke liedstrofe deur alvorens besluit word op die mees geskikte lied om 'n bepaalde funksie in die liturgie te verrig? Die vraag, 'Wat maak die teks die moeite werd om gesing te word?', behoort aan die orde te kom. Tydens hierdie element van die erediens word kommunikasie bewerkstellig waaraan die gemeente aktief deelneem en in gesprek met God en met mekaar tree. Dit is dus belangrik dat die woorde wat gesing word aan die doel van die erediens beantwoord ter wille van die integriteit daarvan en ter wille van die lidmate se spiritualiteit.

In 'n onlangse artikel het Kloppers (2013) aandag gegee aan redes waarom sekere liedere nie gesing word nie. Haar 
identifisering van moontlike redes is op haar eie ervaring oor baie jare gebaseer, maar dit word ongelukkig nie deur empiriese gegewens ten opsigte van spesifieke liedere ondersteun nie. Sy onderskei 'n verskeidenheid faktore wat 'n rol kan speel:

- Musikale faktore: 'n melodie is onbekend of te moeilik.

- Antropologiese, sosiologiese en psigologiese faktore: 'n melodie val nie in mense se smaak nie; die wêreldbeeld of beelde in ' $n$ teks druis in teen die wêreldbeeld van die huidige gebruikers.

- 'n Teologiese faktor: 'n gebrekkige bewussyn van die kerklike jaar.

- Liturgies-teologiese faktore: 'n duidelike plek of funksie in die erediens ontbreek; die liturgiese moontlikheid van die lied is onbekend.

- Fisiologiese (fisiese) en psigiese faktore: die liedere is te lank om as eenheid te funksioneer.

- Daar is tekstuele faktore of ' $n$ wanverhouding tussen die musiek en die teks.

Baie van die faktore het ook in hierdie studie na vore gekom. Haar standpunt dat 'n wisselwerking van faktore by die beoordeling van die rede(s) waarom 'n sekere lied nie gesing word nie, in ag geneem moet word, word in hierdie studie onderskryf, al word hier op die musikale aspek van 'n aantal liedere gefokus.

Dit is inderdaad so dat sekere liedere min gesing word as gevolg van die inhoud en nie as gevolg van die melodie nie, byvoorbeeld Psalm 137, waarna reeds verwys is. In die ondersoek waaroor hier verslag gedoen word, is gevind dat Psalm 74 baie min gesing word (vgl. Van Rooy 2009:358, 360, 361). Die melodie kan nie die rede wees nie, omdat die psalm die melodie van Psalm 116 gebruik, wat een van die gewildste psalms is. In die opname wat gedoen is, is Psalm 116 elf keer meer gesing as Psalm 74, terwyl Psalm 74 omtrent een en 'n half keer so lank soos Psalm 116 is (17 teenoor 10 strofes in die 1936-beryming). In hierdie geval speel die melodie dus nie 'n rol nie. 'n Mens sou kon spekuleer oor die moontlike rede waarom dit so is, byvoorbeeld dat Psalm 116 in baie Gereformeerde Kerke tradisioneel tydens die viering van die nagmaal gebruik word.

In 'n vraelys wat uitgestuur is as deel van die empiriese ondersoek waarop hierdie artikel ten dele berus, is lidmate en orreliste gevra om na te dink oor die liedere wat tydens hulle laaste besoek aan die kerk gesing is, ten einde enkele stellings na aanleiding daarvan te beoordeel. Die respondente kon meer as een moontlikheid kies. Die reaksie kan soos volg in Tabel 1 saamgevat word (vgl. Van Rooy 2009:414):

Hieruit is dit duidelik dat die lidmate en tot 'n mindere mate die orreliste nie die eenheid wat daar tussen woord en toon behoort te wees, na behore kon beoordeel nie en dat die meeste klem op die inhoud van die liedere val. Die drie vrae wat oor die melodieë handel, kyk na dieselfde saak uit verskillende hoeke. Daar is nie beduidende verskille tussen die antwoorde van die respondente op hierdie vrae nie.
TABEL 1: Liedere wat gesing is

\begin{tabular}{|c|c|c|}
\hline Redes verskaf & Lidmate (\%) & Orreliste (\%) \\
\hline Ek kan nie onthou wat ons gesing het nie. & 11 & - \\
\hline Die woorde van die liedere het my aangespreek. & 75 & 74 \\
\hline $\begin{array}{l}\text { Ek kan verstaan hoekom die predikant die liedere } \\
\text { laat sing het. }\end{array}$ & 71 & 74 \\
\hline Die melodieë pas by die woorde. & 42 & 51 \\
\hline Die melodie ondersteun die woorde. & 36 & 57 \\
\hline Die melodie en woorde vorm 'n eenheid. & 43 & 51 \\
\hline $\begin{array}{l}\text { Die redes waarom ons die meeste van die } \\
\text { betrokke liedere gesing het, is vir my onduidelik. }\end{array}$ & 3 & 6 \\
\hline $\begin{array}{l}\text { Ek het bewustelik oor die woorde nagedink terwyl die } \\
\text { liedere gesing is. }\end{array}$ & 60 & 40 \\
\hline
\end{tabular}

Verder moet in gedagte gehou word dat die opmerkings gemaak word na aanleiding van liedere wat op die een of ander manier as geskik vir die betrokke diens beskou is.

Predikante is in 'n onderhoud gevra na die rol wat die lied in die geloofsopbou van die gemeente speel. Hulle was almal positief hieroor. Die volgende sake het aan die lig gekom: dit is 'n gesprek met God; dit dien saam met die prediking tot die geloofsopbou en versterking van die lidmate; die hele liturgie is daarop gerig om die Here te ontmoet; dit dien tot die geloofsopbou en die verhouding van die gemeente onderling en daar is emosionele en geestelike uitdrukkingswaarde opgesluit wat iets vaster maak omdat dit gesing word. Die lied werk dus binne-in die kerkganger en weerklink ook na buite as bevestiging van die geloof van die kerkganger (Van Rooy 2009:592-611).

In die terugvoer oor die gebruiksfrekwensie van liedere (wat hierna aan die orde kom), kom dit meermale voor dat 'n melodie as die rede aangevoer word waarom 'n bepaalde lied nie gesing word nie (Van Rooy 2009:365-367). Melodieë word maklik as onsingbaar beskryf. Olivier (2001:42) meen egter dat 'n vokale melodie net onsingbaar is wanneer dit die omvang en tegniese vermoë van die menslike stem oorskry, dit wil sê indien die melodie eerder vir ' $n$ instrument as die menslike stem geskryf is. Daar is ' $n$ paar maatstawwe wat aangelê kan word by die beoordeling of ' $n$ melodie geskik is. Die melodie en teks behoort byvoorbeeld 'n eenheid te vorm. Indien die frasestruktuur of die aksentpatroon van die melodie van die teks verskil, ontstaan 'n onnatuurlike verhouding wat as gedwonge woord-toonverhouding beskou word. Dit gebeur wanneer die teks 'n punt bevat wat die einde van 'n sin of gedagte aandui, maar die melodie deurloop na die volgende sin van die teks ('n enjambement genoem), of wanneer beklemtoonde lettergrepe op onbeklemtoonde note val, of omgekeerd. 'n Volgende rede wat aangevoer word waarom mense ' $n$ lied negatief beoordeel, is vanweë die tempo; dit is moontlik te traag (vgl. Smelik 1999:131).

\section{Empiriese ondersoek}

In 'n empiriese studie oor die stand van die kerklied in die Gereformeerde Kerke in Suid-Afrika (GKSA) is gevind dat liedere met 'n baie lae gebruiksfrekwensie in liedboeke voorkom (Van Rooy 2009). Die ondersoek het soos volg verloop: 
- In fase 1 is ' $n$ versoek aan predikante van die GKSA gerig om 'n opgawe te voorsien van die liedere wat gedurende een jaar tydens eredienste gesing is.

- In fase 2 is drie verskillende vraelyste uitgestuur aan predikante, orreliste en lidmate van die GKSA. Die vraelyste dek 'n verskeidenheid sake, waaronder die frekwensie van die sing van sekere liedere. Die keuse van liedere is bepaal deur die terugvoer wat uit fase 1 verkry is, met 'n keuse van liedere wat enersyds weinig gesing word en andersyds nuwe liedere wat gou ingang gevind het. Wat die spesifieke liedere betref waaroor navraag gedoen is, is verskillende lyste aan gemeentes gestuur wat verskillende psalmboeke gebruik. ${ }^{1}$

- In fase 3 is onderhoude met vyf predikante en vyf orreliste (uit vyf gemeentes) gevoer aan die hand van 'n basiese skema wat opgestel is op grond van die inligting wat in fase 1 en 2 bekom is (Van Rooy 2009:591-611). Vir volledige inligting oor die ondersoek en die persone wat by die drie fases betrokke was, vergelyk Van Rooy (2009:309-311).

In die lig van hierdie uitkoms is vyf liedere uit Psalmboek (2003) gekies waarvan die melodie ontleed word, om te bepaal wat die invloed daarvan op die lae gebruiksfrekwensie van die betrokke lied mag wees. Die volgende liedere is gekies: Psalm 3 (1936-beryming), Psalm 22 (1936-beryming en 2001-omdigting, ook in die Liedboek 2001), Psalm 120 (1936-beryming, melodie van 1976), Skrifberymings 2-3 en 11-1. Al hierdie liedere is ook in Psalmboek (2000) en berymings van Totius, sodat moontlike weerstand teen die 2001-omdigting nie 'n rol in die gebruiksfrekwensie van die liedere kon gespeel het nie.

Uit 'n totaal van meer as 15000 keer wat die liedere in kerke gesing is waar opnames gemaak is, is die betrokke weergawe van Psalm 3 nie een keer gesing nie (Van Rooy 2009:357). As deel van die ondersoek is in fase 2 'n lys van 20 liedere aan predikante, orreliste en lidmate van kerke wat Psalmboek (2000) gebruik, gestuur en 'n lys van 21 liedere aan diegene wat Psalmboek (2003) gebruik, om te vra of die betrokke liedere wel gebruik word en indien nie, waarom nie. ' $n$ Klein minderheid het aangedui dat hulle die betrokke liedere ken, terwyl dit veral aan die meerderheid lidmate onbekend was. Die belangrikste redes waarom die liedere nie gesing word nie, was deels liturgiese onbruikbaarheid en grotendeels weens die melodie (Van Rooy 2009:366-368). Alhoewel die liedere aan sommige lidmate bekend was, is dit gedurende die betrokke jaar nie in eredienste gesing nie. Hierdie liedere is juis vir hierdie ondersoek gekies omdat dit nie gesing is nie. Dit bevat 'n Geneefse melodie en 'n lang strofebou. 'n Aspek wat in die gebruik van Geneefse melodieë vir 'n Afrikaanse psalmberyming in gedagte gehou moet word, hang saam met die ontstaansgeskiedenis van die Geneefse melodieë. By die Geneefse psalmberyming het die Franse teks die melodie voorafgegaan, sodat die melodie by die teks moes aansluit. Wanneer die melodieë vir Psalmboek (2003). Eersgenoemde bevat die 150 psalms in die 1936-beryming (grotendeels van J.D. du Toit) en 'n aantal skrifberymings. Die 2003-Psalmboek bevat hierdie liedere asook die 2001-omdigting (grotendeels van T.T. Cloete). 'n Afrikaanse beryming gebruik word, moet die teks by die melodie aansluit. Die ritmiese struktuur van Afrikaans as Germaanse taal is anders as dié van Frans wat 'n Romaanse taal is (vgl. Strydom 1999:18-19). Du Plooy (2006) stel dit soos volg:

Die Geneefse melodieë was nie vir Afrikaanse woorde gemaak nie en dit neem 'n vaardige digter om die Afrikaanse taalritme en die Geneefse musikale ritme in goeie poësie te versoen. Die vloei van die Geneefse musiek geskied per reël en Afrikaans het nogal 'n gemarkeerde Germaanse woordritme. (bl. 47)

Vir Psalm 22 word dieselfde melodie by die 1936-beryming en die 2001-omdigting gebruik. Uit die opname blyk dit dat die psalm in die 1936-beryming nege keer gesing is en drie keer in die 2001-omdigting (Van Rooy 2009:357). Alhoewel ' $n$ beduidende hoeveelheid predikante, orreliste en lidmate aangedui het dat hulle die lied ken, is die melodie as een van die vernaamste redes aangedui waarom die lied min gesing word. Die bekendheid van die psalm kan waarskynlik toegeskryf word aan die beginwoorde: 'My God, my God, waarom het U my verlaat?' - 'n aanhaling van een van Jesus se kruiswoorde. Psalm 22 is juis gekies omdat dit een van die psalms is wat deur Jesus aan die kruis aangehaal is en die inhoud van die psalm dus goed bekend is, alhoewel die psalm relatief min gesing word.

Die bespreking van Psalm 120 hou verband met 'n melodie wat vir die 1936-beryming gebruik is. Soos Psalm 3 in die 1936-beryming, is ook hierdie psalm nooit gesing nie (Van Rooy 2009:358). Die psalm is gekies omdat dit klaarblyklik min gesing word en omdat dit een van die melodieë van die hersiene uitgawe van die psalmboek van 1976 het. Skrifberyming 2-3 kom in albei psalmboeke voor en is in totaal nege keer gesing. Dit is gekies omdat dit ' $n$ beryming van ' $n$ gedeelte uit Openbaring is en baie van die ander liedere uit Openbaring dikwels gesing word, maar hierdie een egter nie. Skrifberyming 11-1 kom ook in albei boeke voor en is in totaal 24 keer gesing (Van Rooy 2009:359). Die lied is gekies omdat dit'n melodie het wat spesifiek vir hierdie lied gekomponeer is deur ds. J.V. Coetzee. Hy het 'n belangrike rol in die musikale verwerking van die melodieë vir die oorspronklike uitgawe van die psalmboek in 1937 gespeel.

Die aard van die vyf liedere is ook verskillend. Psalm 3 en 22 is klaagliedere van ' $n$ enkeling. ' $n$ Mens sou kon dink dat hierdie feit alleen ten grondslag sou kon lê van 'n lae gebruiksfrekwensie. Die klaaglied van 'n enkeling is die grootste groep van al die verskillende soorte psalms in die psalmbundel. Daar is egter ' $n$ hele aantal klaagliedere van 'n enkeling wat volgens die empiriese ondersoek 'n hoë gebruiksfrekwensie het, byvoorbeeld Psalm 25, 38, 42 en 51 (vgl. Van Rooy 2009:357). Bloot die feit dat 'n psalm 'n klaaglied is, het nie noodwendig tot gevolg dat die psalm minder in 'n erediens gebruik sal word nie. Psalm 120 is weer 'n danklied van ' $n$ enkeling vir verlossing. Dit blyk beter ontvang te wees uit die beryming van T.T. Cloete as uit die beryming van J.D. du Toit. Skrifberyming 2-3 is 'n beryming van Openbaring 11:15-19, 'n lied wat van God se grootheid en oorwinning sing. Skrifberyming $11-1$ is ' $n$ beryming van 
die troosuitspraak waarmee die tweede deel van Jesaja begin (Jes 40:1-11). Dit is dus 'n lied van troos en verlossing. Die melodieë se herkoms verskil ook.

Psalm 3 en 22 het Geneefse melodieë, Psalm 120 se melodie dateer uit die hersiening van die psalmboek in 1976, Skrifberyming 2-3 is 'n aanpassing van'n melodie van Gesius uit 1600 en Skrifberyming 11-1 se melodie is van ds. J.V. Coetzee, spesifiek gekomponeer vir hierdie Skrifberyming.

\section{Die melodieë van 'n aantal liedere met'n lae gebruiksfrekwensie Psalm 3 (1936)}

Psalm 3 is 'n klaaglied van 'n enkeling. In hierdie psalm verwys die digter eers na sy vyande, spreek daarna sy vertroue in God uit en vra aan die einde dat Hy sy vyande sal verslaan (vgl. Figuur 1). Psalm 3 het in die 2001-omdigting 'n ander melodie gebruik met vier reëls per strofe, teenoor die 12 reëls van die 1936-beryming. Die nuwe weergawe is slegs drie keer gesing.

Op hierdie stadium is dit noodsaaklik om kortliks aandag te gee aan enkele kenmerke van die Geneefse melodieë ${ }^{2}$ wat vir die bespreking van belang is. Strydom (1999:17-23) gee uitvoerig aandag aan die saak van die struktuur van hierdie melodieë. Hiervolgens word die Geneefse melodie

2.Geneefse melodieë verwys na melodieë wat in die Geneefse psalmboeke van die sestiende eeu opgeneem is, veral die uitgawe van 1562.

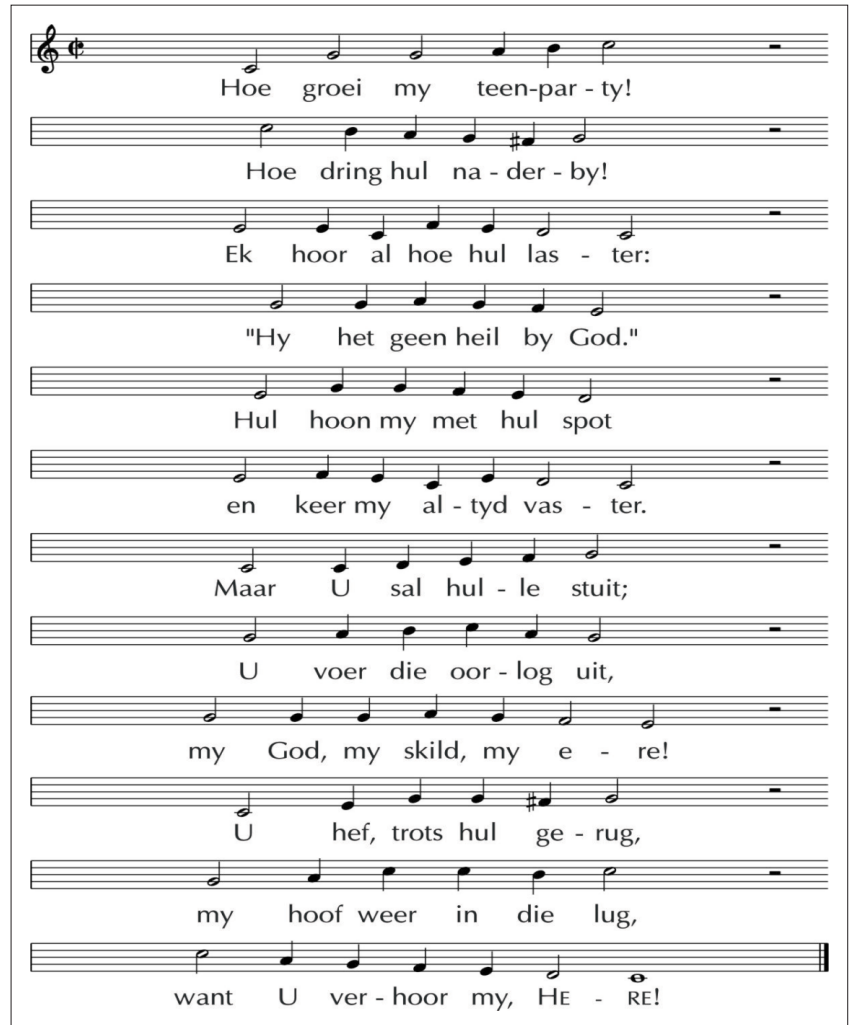

Bron: Psalmboek, 2000, Die berymde psalms in gebruik by die Nederduitse Gereformeerde Kerk, die Gereformeerde Kerke in Suid-Afrika en die Nederduitsch Hervormde Kerk van Afrika en Skrifberymings in gebruik by die Gereformeerde Kerke in Suid-Afrika, Calvyn Jubelium Boekefonds, Potchefstroom

FIGUUR 1: Psalm 3. nie deur 'n vaste maatgebonde metrumstelsel gekenmerk nie, maar dit is mensurale musiek. Die melodiese ritme word deur die woordritme bepaal wat oor 'n polsslagstruktuur (polsslag = tactus) beskik wat konsekwent gehandhaaf moet word. Die tactus word beskryf as die tydsduur wat verloop tussen die sametrekking en die ontspanning van die hartspier, tussen twee slae van die pols of tussen twee voetstappe van 'n rustig-lopende mens - ongeveer 72 polsslae per minuut. Halfnootwaardes word normaalweg aan die begin en einde van 'n versreël aangetref. Langer nootwaardes word soms gebruik om belangrike woorde in die teks te onderstreep, maar dit kan ook op die ritmiese struktuur van die melodie dui. Laastens vorm die lang slotnootwaardes, saam met die aanvangsnootwaarde van 'n frase, die ritmiese en melodiese steunpunte van die melodie. Dus word by elke frase voortgestu vanaf die eerste afslag van die frase na die slot- of doelnoot toe. Die korter nootwaardes tussenin verkry aksentuering in ooreenstemming met die normale woordaksente. Aan die einde van 'n Geneefse frase verskyn 'n kenmerkende halfnootrusteken. Dit is ' $n$ wesenlike element van die musikale frasestruktuur en moet met die uitvoering daarvan eerbiedig word. Waar geen rus is nie, word die polsslag gehandhaaf en die stuwing gaan voort.

Die melodie van Psalm 3 het 'n skema van vier sinne $(3+3+3+3$ frases $)$ wat ongewoon en onreëlmatig is. Dit word daardeur bevestig dat hierdie melodie in die Psalter Hymnal (1988:863), die liedboek van die Christian Reformed Church in Amerika, die enigste melodie met hierdie patroon is. Al die frases is ook verskillend. Omdat die struktuur onreëlmatig is en herhaling van frases ontbreek, is dit 'n lied wat moeilik aanleer. Ritmies is ' $n$ definitiewe patroon teenwoordig, behalwe vir die eerste en die laaste frase wat effens afwyk (soos deur Strydom 1999 bespreek word). Frases 2, 4, 5, 7, 8, 10 en 11 stem presies ooreen, terwyl frases $3,6,9$ en 12 weer ooreenstem.

Die rympatroon in die teks is soos volg: aabccbddeffe. Aan die einde van elke groep van drie versreëls verskyn 'n dubbelrym. Die lettergreeptelling is deurgaans 6, 6, 7. Die reëls met sewe lettergrepe vereis 'n dubbelrym - 'n vereiste wat die melodie stel.

Die melodie is in die ioniese modus gekomponeer en dit is ' $n$ melodie wat voortbeweeg en in elke frase voortstu ${ }^{3}$ na die laaste lang nootwaardes. 'n Klimaks verskyn in frase 11, waarna die spanningslyn met ' $n$ dalende toonleerpassasie in die laaste frase afsluit. Die woordtoonverhouding is oor die algemeen goed behalwe by woorde soos las-ter en vas-ter wat lang nootwaardes op die eerste lettergreep het. Tipies van Geneefse melodieë, begin elke reël van die melodie met ' $n$ halfnoot. Dit kan egter woord-toonverhoudingsprobleme skep, omdat die Afrikaanse teks nie altyd met ooreenstemmende lang lettergrepe begin nie. In die eerste strofe van hierdie Psalm veroorsaak dit byvoorbeeld probleme in reëls 1-6

3.Vir die gebruik van die term voortstu, vergelyk Strydom (1999:21). Die melodiese frase van die Geneefse melodie stu voort na die lang slotnote, wat as die doelnote van die melodiese beweging beskou kan word. 
en 9-11. Die omvang van die melodie beslaan 'n oktaaf (8 toonleertrappe) en die tessituur ${ }^{4}$ lê gemaklik binne die gemiddelde kerkganger se bereik.

Die lengte van die melodie kan 'n probleem wees, maar daar is ander melodieë van 12 reëls in die Psalmboek van 2003 wat nie problematies is nie. Die liedere met 12 reëls wat dikwels gesing word, bevat almal herhalings in die melodie. Hierdie melodieë gaan nie in besonderhede ontleed word nie, maar enkele sake word kortliks genoem om die stelling te staaf. Melodieë soos Psalm 19 en 36 (68 en Skrifberyming 2-2 en 7-1) bevat herhaling. Alhoewel dit uit 12 frases bestaan, is dit bekende en gewilde melodieë in gereformeerde kringe. Streng gesproke bestaan Psalm 47 ook uit 12 frases, maar dit word twee-twee met ' $n$ sinkopee aaneengeskakel. Die teks lyk na ses reëls, maar elke reël het 'n binnerym. Die ritmiese patroon word ses keer herhaal, wat die aanleer vergemaklik, alhoewel daar nie herhaling in die melodie voorkom nie. Die lengte is dus nie noodwendig 'n probleem nie.

Die feit dat die melodie van Psalm 3 (1936) geen herhalings van frases bevat nie en die frasestruktuur onreëlmatig is, speel waarskynlik 'n rol daarin dat dit nie aanvaarbaar bevind is nie en ook nie gesing word nie. Dit stem ooreen met opmerkings van Kloppenburg (1991) in verband met onreëlmatige melodieë. Hy verwys na 'n studie oor die frekwensie van die aanhaling van berymde psalms in die sestiende tot agtiende eeu, waarin onder andere 36 melodieë met 'n lae gebruiksfrekwensie ondersoek is. In aansluiting hierby maak hy opmerkings oor sy eie ervaring, naamlik dat korter melodieë eerder meer gebruik word as langer melodieë (Kloppenburg 1991:242-243). Melodieë met 'n unieke strofestruktuur is dus minder toeganklik, lê moeiliker op die oor en word nie maklik aanvaar nie (Kloppenburg 1991:243).

\section{Psalm 22 (1936 en 2001)}

Psalm 22 is ook 'n klaaglied van 'n enkeling (vgl. Figuur 2). Dieselfde melodie word in albei psalmboeke gebruik en is oorspronklik deur Guillaume Franc gekomponeer vir die Franse beryming van die psalm: 'Mon Dieu, mon Dieu, pourquoy m'as-tu laissé' (1542) te Genève. Die bespreking oor die tipiese eienskappe van die Geneefse melodieë is ook hier van toepassing, in aansluiting by die bespreking van Strydom (1999) waarna hierbo verwys is.

Die melodie bestaan uit agt frases (twee sinne van vier frases elk). Frases 4 en 8 is korter frases wat die twee sinne afsluit. Die modus is eolies (mineur met verlaagde leitoon ${ }^{5}$ ). Frases 2 en 3 en 6 en 7 is in G-majeur. Frase 5 moduleer vanaf e-mineur na G-majeur. In frase 5 en 6 word herhalings aangetref. Albei frases begin op dieselfde toonhoogte B (wat drie keer herhaal word) en is ritmies ooreenstemmend. Verder word geen herhaling aangetref nie.

4.Die term dui op daardie deel van die stemomvang waarbinne met gemak gesing kan word (Ottermann \& Smit 2000:243)

5.Die feit dat $D \#$ in die e-mineurkadense gebruik is, versterk die effek van e-mineur in die vierstemmige besetting. Die leitoon word in die begeleiding aan die einde van die twee frases verhoog (vgl. Begeleiersboek 2004:86).

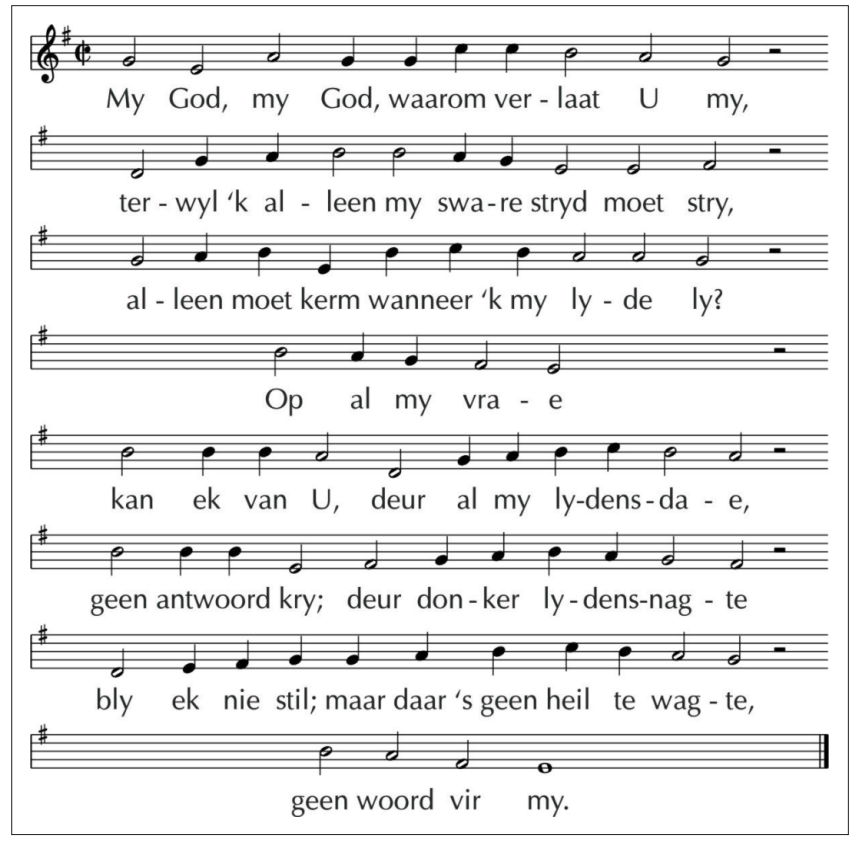

Bron: Psalmboek, 2000, Die berymde psalms in gebruik by die Nederduitse Gereformeerde Kerk, die Gereformeerde Kerke in Suid-Afrika en die Nederduitsch Hervormde Kerk van Afrika en Skrifberymings in gebruik by die Gereformeerde Kerke in Suid-Afrika, Calvyn Jubelium Boekefonds, Potchefstroom

FIGUUR 2: Psalm 22.

Die omvang van die melodie beslaan ' $n$ interval van ' $n$ mineur septiem (sewende) en die ligging van die tessituur lê gemaklik binne die stemomvang van die deursnee kerkganger. Die melodie bevat geen besondere hoogtepunt nie, maar daar is deurlopend voortstuwende lyne wat op en af beweeg en geskik is vir ' $n$ teks van hierdie aard. Frases 1 , 2, 3, 5, 6 en 7 is baie lank met geen binnesesuur nie. ${ }^{6}$ Die volledige frase behoort in een asem deurgesing te word, wat die uitvoering daarvan bemoeilik. Die lettergreeptelling is $10,10,10,5,11,11,11,4$. Die teks bestaan uit 12 strofes.

Die woord-toonverhouding van die 1936-beryming is nie geslaagd nie. Waarskynlik het frases 4 en 5 groot probleme aan die digter besorg. Problematiese enjambemente kom deurgaans voor. Enjambemente kom algemeen in poësie voor en is gewoonlik nie ' $n$ probleem nie. By die voorlees van 'n gedig kan iemand hom by die taalstruktuur aanpas om so die enjambemente te oorbrug. In 'n lied kan dit egter problematies wees wanneer ' $n$ frase van 'n sin van die teks oor die einde van 'n musikale reël loop en veral wanneer daardie musikale reël op 'n rusteken eindig. In sulke gevalle word die gedagtegang van die lied deur 'n rusteken onderbreek. 'n Voorbeeld van problematiese enjambemente kom voor in die eerste drie reëls van Totius se Psalm 96:2, waar die uitdrukking, 'onder die volke', deur 'n rusteken in die melodie geskei word. In Psalm 22 vereis die melodie 'n afsluiting aan die einde van frase 4, terwyl die teks 'n deurgang na reël 5 vereis. In die meeste strofes vorm frase 4 en 5 in die teks 'n eenheid, wat deur die afsluiting na frase 4 onderbreek word. 'n Uitsondering word by strofe 5 aangetref, waar die musikale sin en die liedteks in frase 4 saamval en afsluit. Die woord-toonverhouding val nie oral natuurlik op 6.' $n$ Sesuur is ' $n$ asemhalingsgeleentheid wat ' $n$ tactus of ' $n$ halwe tactus kan duur (Strydom 1999:23). 
die tong nie, met byvoorbeeld kort lettergrepe op langer nootwaardes, soos by die woorde God, ter-wyl, stryd, al-leen om enkele probleme in strofe 1 te noem. Dieselfde tendens kom voor by die 2001-omdigting in strofe 1, frase 1 , byvoorbeeld by die woorde God op die halfnootwaarde dan en ver-laat.

Tesame met die lang frases bied die enjambemente, die problematiese woord-toonverhouding en die moeilike melodiese struktuur 'n moontlike verklaring waarom Psalm 22 byna nooit gesing word nie. In die 2001-omdigting kom geen enjambemente voor nie, en dit is net drie keer in gemeentes waarvan terugvoer ontvang is, gesing. Die inhoud van die lied sou op Goeie Vrydag goed aan die orde kan kom, weens die aanhaling van die beginwoorde van die Psalm deur Jesus aan die kruis. Die feit dat die lied egter baie min gesing word, mag dus onder andere met die melodie verband hou.

\section{Psalm 120 (1936-beryming, melodie van 1976)}

Hierdie is 'n danklied van 'n enkeling: Die melodie is in 1976 deur Pieter van der Westhuizen gekomponeer (vgl. Figuur 3). Met die hersiening van die psalmboek in 1976 het dit die sogenaamde Nuwe wysie van die uitgawe van die psalmboek in 1937 vervang. ${ }^{7}$ Die styl is Geneefs, maar dit toon geen ooreenkoms met die oorspronklike melodie van Louis Bourgeois nie. (Daardie melodie het al in 1937 met die verskyning van die eerste Afrikaanse beryming plek gemaak vir'n P.K. de Villiers-melodie.)

Die melodie is in die Doriese toonaard geskryf en bestaan uit ses frases. Frase 1 begin in die Doriese modus en sluit af in F-majeur. Frase 2 keer terug in die Doriese modus, frase 3 sluit af in a-mineur, frase 4 is in F-majeur en frases 5 en 6 is terug in die oorspronklike toonaard. Die moderne mens se oor is op 'n majeur- of mineurklank ingestel. Dit klink vreemd op die oor om te sing in 'n modus waaraan die deursnee oor nie blootgestel word nie (vgl. Van der Walt 1962:59, 84, 92). Dit verklaar dalk waarom die psalm nie gesing word nie.

7.Die Nuwe wysie van 1937 was'n P.K. de Villiers-melodie, volgens die Koraalboek (1956)

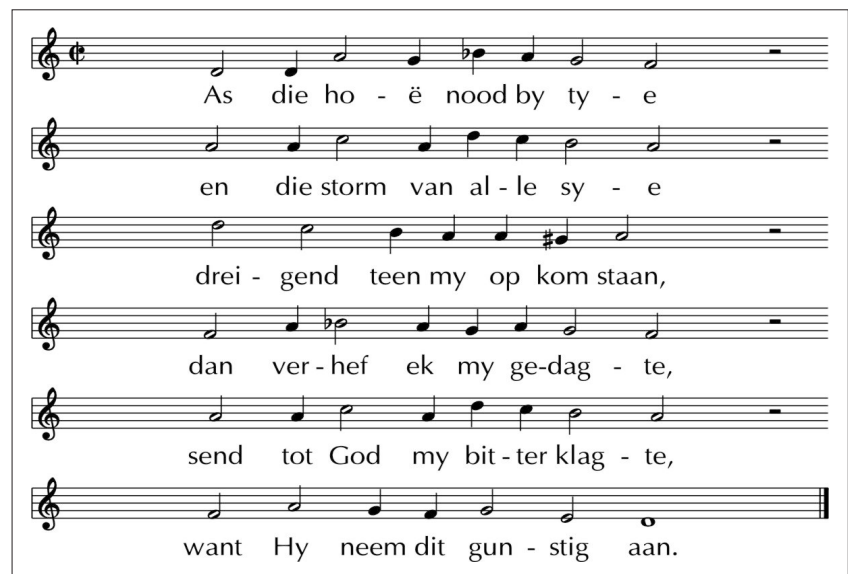

Bron: Psalmboek, 2000, Die berymde psalms in gebruik by die Nederduitse Gereformeerde Kerk, die Gereformeerde Kerke in Suid-Afrika en die Nederduitsch Hervormde Kerk van Afrika en Skrifberymings in gebruik by die Gereformeerde Kerke in Suid-Afrika, Calvyn Jubelium Boekefonds, Potchefstroom

FIGUUR 3: Psalm 120.
Wat aspekte soos ritme, struktuur, melodiese voortstuwing, toonhoogte, omvang, fraselengte en tessituur betref, is daar nie juis iets vreemds nie, alhoewel die sinkopasie in reël 1, 2, 4 en 5 nie so algemeen is nie. Die ritme pas presies in die aard van die Geneefse styl. Frases 1, 2, 4 en 5 stem ritmies ooreen, terwyl frases 3 en 6 verskil. Die struktuur is ABCDBE (frase 5 is ' $n$ herhaling van frase 2), terwyl frase 2 'n gewysigde sekwens van frase 1 is. Daar kom dus genoegsame herhaling in die melodie voor. Die omvang dek die afstand van 'n oktaaf en die tessituur het 'n gemaklike ligging vir die deursnee kerkganger, met die enigste moontlike uitsondering die hoë D aan die begin van reël 3. Die frases het gemaklike lengtes en behoort in een asem gesing te kan word. Nêrens word ongewone spronge in die melodie aangetref nie, maar vanweë die modale aard en die wisseling van toonwaarde, is dit moeilik om sekere intervalle suiwer te intoneer. ${ }^{8}$

Die melodie pas by die karakter van Psalm 120. Die rympatroon van die teks is aabccb met dubbelryme by aa en cc. Die woord-toonverhouding is nie oral geslaagd nie. In strofe 1 kan die volgende voorbeelde uitgelig word: die openingshalfnootwaarde val op 'n kort lettergreep, As. Net so val die -e van tye en sye op halfnootwaardes. Soortgelyke gevalle kom verderaan in die strofe, asook in die oorblywende strofes voor. Dit dui daarop dat hierdie styl nie vir die Afrikaanse teks geskik is nie.

\section{Skrifberyming 2-3}

Skrifberyming $2-3$ is ' $n$ beryming van J.D. du Toit uit Openbaring 11:15-19 (vgl. Figuur 4). In die psalmboek is daar beslis ' $n$ behoefte aan meer Nuwe-Testamentiese liedere.

Die melodie is ' $n$ Middeleeuse lied wat in verskillende weergawes voorkom. Dit hang van die oorspronklik Latynse weergawe af of dit met of sonder 'n Halleluja gesing word en of daar langer of korter refreine is. Die komponis is Gesius wat dit oorspronklik vir die lied 'Heut triumphieret Gottes 8.Dit beteken, om op die regte toonhoogte te sing.

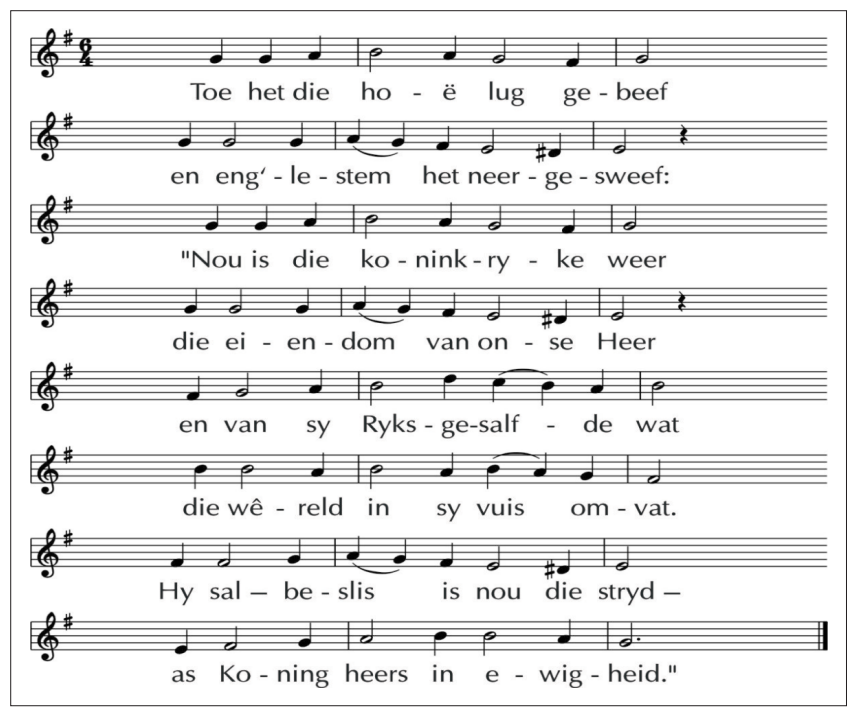

Bron: Psalmboek, 2000, Die berymde psalms in gebruik by die Nederduitse Gereformeerde Kerk, die Gereformeerde Kerke in Suid-Afrika en die Nederduitsch Hervormde Kerk van Afrika en Skrifberymings in gebruik by die Gereformeerde Kerke in Suid-Afrika, Calvyn Jubelium Boekefonds, Potchefstroom

FIGUUR 4: Skrifberyming 2-3. 


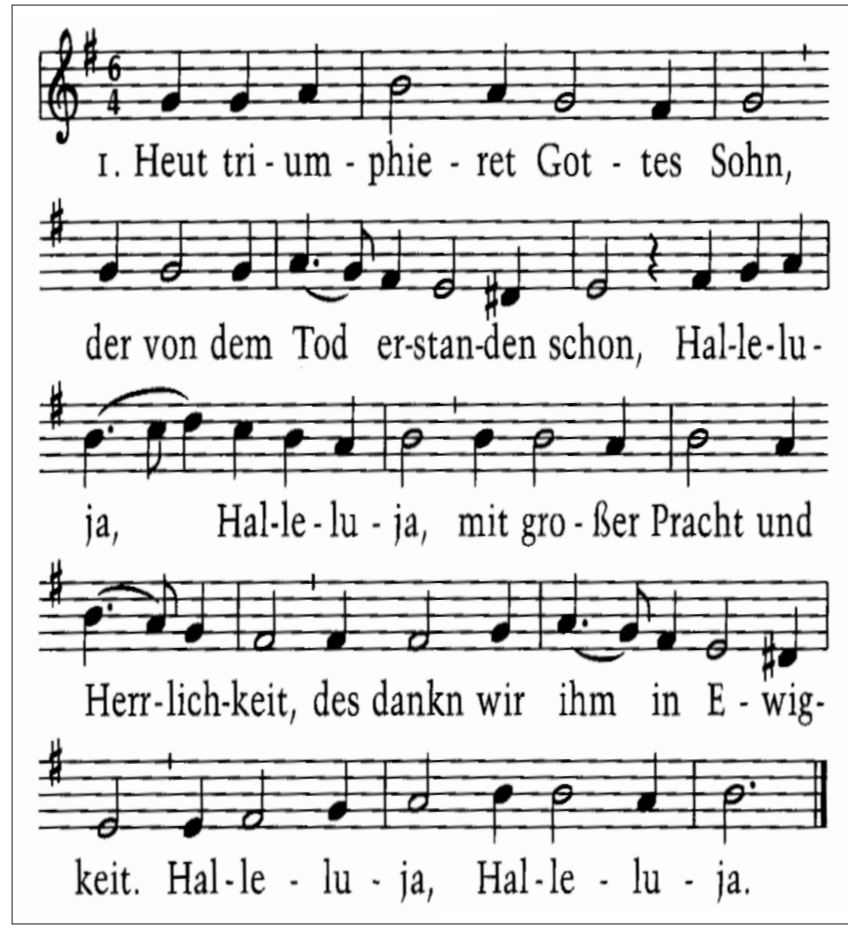

Bron: Lutherische Kirche, 1994, Evangelische Gesangbuch: Ausgabe für die EvangelischLutherischen Kirchen in Niedersachse und für die Bremische Evangelische Kirche, Lutherisches Verlagshaus, Hannover

FIGUUR 5: Skrifberyming 2-3: Duitse weergawe.

Sohn' (1600) gekomponeer het (Kloppenburg 1977:406-407). Omdat die melodie vir hierdie skrifberyming aangepas is, volg die Duitse weergawe hieronder (vgl. Figuur 5).

Skrifberyming 2-3 is in barvorm geskryf en bestaan uit agt frases. Frase 1 en 2 word herhaal om die Stollen te vorm en die Abgesang bestaan uit vier frases. Die melodie het dus die tipiese AAB-vorm van 'n lied met die barvorm. Vir Skrifberyming 2-3 is die melodie aangepas om by die teks te pas. Die struktuur van die melodie in Psalmboek (2003) is ABABCDBE. Die rympatroon van die teks is aabbccdd. Die toonaard is G-majeur. Frases 2, 4 en 7 moduleer na e-mineur. Getrou aan die vorm is frase 4 ' $n$ herhaling van frase 2 . Frase 7 is effens gewysig in die eerste twee tone van die melodie, maar die res van die frase kom presies ooreen met frase 2 . Die lettergreeptelling is $8,8,8,8,8,8,8,8$, maar tog vloei die melodie nie gemaklik nie - waarskynlik vanweë die aanpassing(s) wat gemaak is. Dit is asof die melodie doelloos rondom sekere tone konsentreer en nie rigting kry nie.

Die oorspronklike melodie (Liedboek 1996:311, Gesang 205) is nie in barvorm nie. Dit bestaan uit ses frases. Die melismas is in Psalmboek (2003) aangepas. In plaas van 'n gepunteerde kwartnoot gevolg deur 'n agstenoot verskyn dit as twee kwartnote. Die maatsoort is verskillend: drie kwartnote per maat in die Liedboek (1996) teenoor 'n saamgestelde tweeslagmaat (6 kwartnote per maat) in die Psalmboek (2003) en die Evangelisches Gesangbuch (Lutherische Kirche 1994, lied 109). By Skrifberyming 2-3 (frase 5) is 'n melisma verwyder (waarskynlik om die hallelujas te omseil) en vervang met 'n halfnootwaarde. Dit veroorsaak dat die melodie stol en nie na die doelnoot voortbeweeg nie.

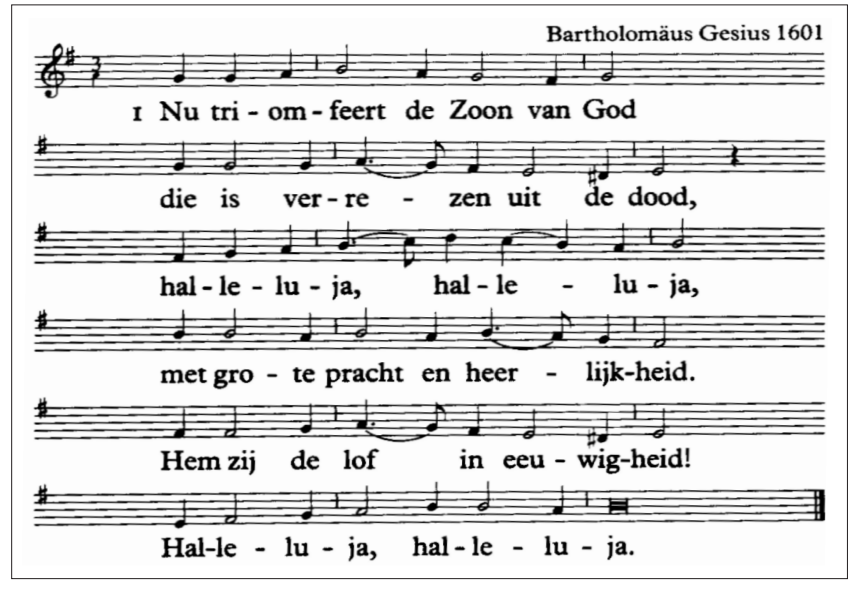

Bron: Liedboek, 1996, Liedboek voor de kerken, 6e uitg., Boekencentrum, Zoetermeer FIGUUR 6: 'Nu triomfeert de Zoon van God.'

In die Liedboek voor de Kerken (Gesang 205; Liedboek 1996) is dit ' $\mathrm{n}$ Paaslied onder die titel: 'Nu triomfeert de Zoon van God (vgl. Figuur 6)'. Dit sluit direk aan by die teks van die oorspronklike Duitse lied. In hierdie weergawe verskyn daar in frases 3 en 6 halleluja-refreine wat aan die karakter van die melodie ' $n$ totaal ander dimensie verleen en voortstu na die halleluja.

Dit blyk dus dat die melodie, waarvan die karakter so verander en aangepas is om by die struktuur en die teks te pas, nie 'n suksesvolle poging is nie. Tans is die alternatief vir hierdie melodie dié van Psalm 147, óf die Pieter van der Westhuizen-weergawe (1976), óf die P.K. de Villiersweergawe (1922/1937).

\section{Skrifberyming 11-1}

Hierdie lied (vgl. Figuur 7) is net in die lys van liedere in die vraelys opgeneem vir diegene wat Psalmboek (2000) gebruik. Hierdie vraelys was deel van fase 2 van die ondersoek, waarna bo verwys is. Die melodie is soos volg:

Skrifberyming $11-1$ is 'n beryming van Jesaja 40:1-11. Die komponis is J.V. Coetzee (1935; destyds predikant van die Gereformeerde Kerk Potchefstroom). Dit bestaan uit vier frases wat in D-majeur geskryf is en in frase 2 na A-majeur (die dominant-toonsoort) moduleer. Daar is 'n goeie balans tussen spronge en 'n trapsgewyse beweging met 'n voortstuwende melodie wat aangenaam op die oor klink. Ritmies is variasie en herhaling ingesluit: frases 1 en 3 en frases 2 en 4 stem ooreen. Melodies kom herhaling voor. Die laaste vier tone in frases 1 en 3 stem presies ooreen en in frase 4 is dit ' $n$ terts laer. Die struktuur is ABCD, die lettergreeptelling is $9,8,9,8$ en die rympatroon is abcb.

Daar ontbreek dus nie veel om 'n singbare melodie te wees nie. Struktureel beantwoord dit aan die basiese vereistes soos dit blyk uit die herhaling van die laaste drie mate van frase 1 in frase 3. Wat die woord-toonverhouding aanbetref, kan die volgende aangetoon word: strofe 1, frase 1 se herhaling van die woord troos val op 'n kort nootwaarde, terwyl dit 'n lang vokaal het; en die woord 


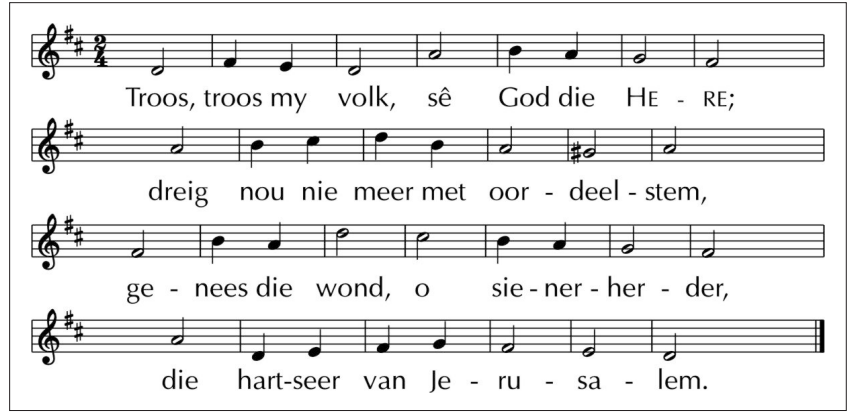

Bron: Psalmboek, 2003, Die berymde en omgedigte psalms en ander skrifberyminge in gebruik by die Gereformeerde Kerke in Suid-Afrika, NG Kerkuitgewers, Wellington

FIGUUR 7: Skrifberyming 11-1.

volk het 'n kort vokaal wat op 'n lang nootwaarde gesing word. Dieselfde geld vir die woorde ge-, wond, her- in frase 3 en die woorde die en Je-ru-sa-lem in frase 4; vir strofe 2, frase 1 , met die eerste woord vertel, val ver- op 'n lang nootwaarde ('n volle maat) wat nie 'n gelukkige woord-toonhuwelik is nie; vir frase 3 , met die woorde dat, ont-vang, het, han-de en vir frase 4, waar die woord $d u b$ bel dieselfde probleem het. Swak woord-toonverhouding kom deurgaans voor. Dit verklaar waarom die lied selde deel van die liturgie van die eredienste vorm. Indien Skrifberyming 11-1 aan hedendaagse vereistes moet voldoen, sal dit nie slaag nie. Twee kwartnootwaardes per maat is ook nie bevorderlik vir musikale melodiese vormgewing nie.

Wanneer 'n gemeente kort lettergrepe op lang nootwaardes sing, raak die sang trekkerig. Dit werk verlammend in op die tempo en dit lei daartoe dat die estetiese aard van die kerksang aangetas word.

\section{Konklusie}

Die keuse van liedere vir die gebruik tydens eredienste word deur verskillende sake bepaal, onder andere deur die kennis van die liturg self. Tog blyk dit dat die melodie inderdaad ' $n$ rol speel in die feit dat sommige liedere nooit of min tydens eredienste gesing word. Die volgende konklusies kan egter gemaak word in die lig van die voorafgaande ondersoek en veral die ontleding van die betrokke melodieë.

- Lidmate konsentreer eerder op die woorde wat hulle sing en nie soseer op die melodie nie. Tog beïnvloed die melodie die aanvaarbaarheid van 'n lied meer as waarvan hulle dalk self bewus is.

- Onreëlmatige strukture soos wat in sommige Geneefse melodieë voorkom, is nie vir lidmate so maklik aanvaarbaar in Afrikaanse kerkliedere nie. Hulle verkies eerder die algemene, maklik singbare, reëlmatige strukture wat meestal by Duitse en Engelse liedere voorkom. ${ }^{9}$

- Hoe minder herhaling van frases en ritme voorkom, hoe moeiliker leer die lied aan, wat waarskynlik die geval is by Psalm 3.

- Die Geneefse melodie is oorspronklik vir die soepel Franse taal gekomponeer, terwyl Afrikaans 'n Germaanse 9.Hierdie saak word breedvoerig deur Van der Walt (1962:71-79) bespreek. taal met ' $n$ ander struktuur, ritme en frasering is. Dink aan al die dubbelryme en lang frases soos blyk uit die terugvoer en ontleding van Psalm 3, 22 en 120.

- Die modus waarin die lied geskryf is, speel 'n beduidende rol. Die deursnee kerkganger hoor hoofsaaklik majeur- of mineurtoonwaarde buite die kerk. Die modale melodieë is ongewoon en onbekend by die gewone lidmaat (vgl. Skrifberyming 2-3).

- Die woord-toonverhouding speel 'n groot rol in die aanvaarding van ' $n$ lied, al dan nie. Wanneer 'n gemeente kort lettergrepe op lang nootwaardes sing, raak die sang trekkerig. Dit werk verlammend in op die tempo en lei daartoe dat die estetiese aard van die kerksang aangetas word soos blyk uit die ontleding van Skrifberyming 11-1.

Dit is dus duidelik dat die melodie inderdaad 'n belangrike rol in die lae gebruiksfrekwensie van sekere liedere tydens eredienste kan speel.

\section{Erkenning Mededingende belange}

Die outeur verklaar dat sy geen finansiële of persoonlike verbintenis het met enige party wat haar nadelig kon beïnvloed het in die skryf van hierdie artikel nie.

\section{Literatuurverwysings}

Begeleiersboek, 2004, Psalmboek: Begeleiersboek, NG Kerkuitgewers, Wellington. De Heer, A., 1999, 'Over criteria voor kerkliederen', Eredienst 26(3), 77-87.

Du Plooy, Heilna, 2006, 'Geloof, musiek en taal', Vir die Musiekleier 33, 40-54. (G.G. Cilliers-gedenklesing).

Hoondert, M., 2003, "'Wachters op die morgen": Muziek in de paaswake - Presentatie en evaluatie', Tijdschrift voor Liturgie 87(1), 64-75.

Kennel, G., 2004, 'Die Rolle der Muzik in gottesdienstliche Inszenierung', in E. Mildenberger \& W. Ratzmann (Hrsg.), Klage-Lob-Verkündiging: Gottesdienstliche Musik in einer pluraren Kultur, pp. 91-112, Evangelische Verlagsanstalt, Leipzig.

Kloppenburg, W., 1977, 'Gezang 205, 152', in W.G. Overbosch (red.), Een compendium van achtergrondinformatie by de 491 gezangen uit het 'Lieboek voor de kerken', bl. 406-407, Prof. Dr. G. van der Leeuw-stichting, Amsterdam.

Kloppenburg, W., 1991, 'Psalmlied en Volkslied', in J. de Bruijn (red.), Psalmzingen in de Nederlanden: Vanaf de zestiende eeuw tot heden, bl. 233-244, Kok, Kampen.

Kloppers, E., 2013, “'n Lied moet klink om gehoor te word ... : Faktore wat die resepsie van kerkliedere kan beïnvloed', HTS Teologiese Studies/Theological Studies 69(1), Art. \#1351, 8 pages.

Koraalboek, 1956, Kolraalboek vir gebruik by die Afrikaanse psalms en gesange, Hers Uitg., NG Kerkuitgewers, Kaapstad.

Kruger, D. \& Smit, E.J., 2001, "'Hoe moet dit dan wees?" Gedagtes en riglyne oor die aard en gebruik van die kerklied', Vir die Musiekleier 28, 14-23.

Liedboek, 1996, Liedboek voor de kerken, 6e uitg., Boekencentrum, Zoetermeer.

Liedboek, 2001, Liedboek van die kerk vir gebruik by die erediens en ander byeenkomste, NG Kerkuitgewers, Kaapstad.

Lutherische Kirche, 1994, Evangelische Gesangbuch: Ausgabe für die EvangelischLutherischen Kirchen in Niedersachse und für die Bremische Evangelische Kirche, Lutherisches Verlagshaus, Hannover.

McKinnon, J.W., 2001, 'Christian church, music of the early I', in S. Sadie (ed.), The new Grove dictionary of music and musicians, Vol. 5, 2nd ed., pp. 795-802, Macmillan, Grove dictiondon.
Lond

Olivier, G., 2001, 'Singbare' melodieë', Vir die Musiekleier 28, 42-45.

Ottermann, R. \& Smit, M., 2000, Suid-Afrikaanse musiekwoordeboek/South African music dictionary, Pharos, Kaapstad.

Psalmboek, 2000, Die berymde psalms in gebruik by die Nederduitse Gereformeerde Kerk, die Gereformeerde Kerke in Suid-Afrika en die Nederduitsch Hervormde Kerk van Afrika en Skrifberymings in gebruik by die Gereformeerde Kerke in Suid-Afrika, Calvyn Jubelium Boekefonds (CJBF), Potchefstroom.

Psalmboek, 2003, Die berymde en omgedigte psalms en ander skrifberyminge in gebruik by die Gereformeerde Kerke in Suid-Afrika, NG Kerkuitgewers, Wellington.

Psalter Hymnal, 1988, Psalter Hymnal, CRC Publications, Grand Rapids. 
Ramshaw, G., 1995, 'Words worth singing', The Hymn 46(2), 16-19.

Rössler, M., 1994/1995, 'Lob-Lehre-Labsal: Theologie im Spiegel von Musik, Kirchenlied und Gesangbuch', Jahrbuch für Liturgik und Hymnologie 35, 110-123. Smelik, J., 1998, 'Bijbel en kerklied', Eredienst 25(6), 177-187.

Smelik, J., 1999, 'Omgaan met kerkliederen: Respect voor de diversiteit', Eredienst $26(4), 128-134$

Smelik, J., 2005, Gods lof op de lippen: Aspecten van liturgie en kerkmuziek, Boekencentrum, Zoetermeer.

Strydom, W.M.L., 1999, 'Die ritmiek, frasering en uitvoeringswyse van die Geneefse psalmmelodieë', Vir die Musiekleier 20(27), 17-24.
Van der Walt, J.J.A., 1962, Die Afrikaanse psalmmelodieë, Pro Rege, Potchefstroom.

Van Rooy, J.H., 2009, 'Die Psalmboek 2003 as kommunikasiemiddel in die liturgie van die erediens in die Gereformeerde Kerke in Suid-Afrika: 'n Himnologiese studie', Ph.D.-proefskrif, Fakulteit Teologie, Noordwes-Universiteit, Potchefstroom.

Van Rooy, J.H., 2013, 'Die kerklied en kommunikasie deur woord en melodie', In die Skriflig 47(1), Art. \#82, 9 pages.

Vos, C.J.A., 2005, Theopoetry of the psalms, Protea Book House, Pretoria.

Vos, C.J.A. \& Müller, J.C., 1990, 'Die sing van psalms in die erediens: 'n Kommunikatiewe handelingsteoretiese perspektief', Praktiese Teologie in Suid-Afrika 6(1), 86-98. 